\title{
Hittite Cuisine: fire installations, cooking pottery and foodways in central Anatolia of the Late Bronze Age
}

\author{
GIACOMO CASUCCI \\ Uşaklı Höyük Archaeological Project
}

\section{INTRODUCTION COOKING POTTERY}

Inside the Hittite pottery assemblages of the central Anatolian sites, two main types of cooking vessels can be identified: cooking pots and baking plates. The cooking pots (Fig.1) represent a clearly identifiable group. The main peculiarity is the external thickening of the rim. The texture usually rich in minerals and a globular body with a rounded base and two vertical hands are the other distinctive elements (Müller-Karpe 1988). Such morphology and such rather coarse mixture are functional to prevent the content from boiling and evaporating too quickly (Rice 1987). On the one hand, the great depth makes it quite difficult to access the contents, on the other hand it is ideal for good heat preservation and slow cooking. All these elements, together with the inclination of the walls (between $60^{\circ}$ and $90^{\circ}$ ), suggest that these pots, placed directly on the coals or hung over them thanks to a superstructure, were used to boil foods.

This seems to be proved by the Inandiktepe reliefs vase (Fig.2) and by the text KUB XX 76, I - CTH 634, where a ritual meal is respectively depicted and narrated, in which the food is cooked and served using pots. As proof of the fact that this culinary practice was part of collective imagination there is the Ritual for the God of the Storm of Kuliwišna (Glocker 1997), where at vs.II:5' we can read: "how the wooden ladle calms the pot" ([ma-ah-ḩa-an?] GIŠ ti-pa-aš DUGÚTUL [a-ra-a-iz-zi]).

The so-called Hittite baking plates (Fig.3) form a separate group, not only for their technical properties, but also from a functional and morphological point of view. Characterized by a usually coarse mixture, rich in mineral and vegetal inclusions, and by a commonly thickened and everted rim sometimes bearing rope impressions, they are large vases with a diameter between 30-80 cm (Mielke 2006). Their constant presence within Hittite contexts - both public and private - proves their daily use. The physical characteristics, the traces of secondary burning and the places of discovery (Fig.4) also suggest their use for processing food (roasting, toasting, and sautéing). However, questions about their manufacture and use remain largely open.

\section{THE CASE STUDY OF HITTITE BAKING PLATES}

With the aim of reconstructing the method of production and use of one of the typical pottery forms of the Hittite repertoire, a study is currently being conducted covering several approaches within the Uşaklı Höyük archaeological project. A research that includes both the statistical analysis of the data collected from the description of the samples found during the excavation (e.g. incidence of rope impressions, traces of secondary burning, size of the rim brim) and the attempts to reproduce these tools in the laboratory (by LArS, Laboratory of Experimental Archaeology, Department DSSBC, University of Siena - Fig.5-6) and reuse them according to the information coming from the residue analyses (Fig.7).

\section{FIRE INSTALLATIONS}

Inside the Hittite sites of the central Anatolian Plateau, two main types of fire installations can be identified: hearths and ovens. Hearths are usually documented by simple ash patches, sometimes bound by stones and/or equipped with a thin hardened clay cooking surface applied over a layer of gravel and lime, pottery fragments or stone slabs. Their shape is variable: circular, semi-circular, rectangular. Their location is almost always inside the courtyards or main rooms: in a central position, in front of a wall or near a corner. Examples of outdoor hearths were discovered near some domestic buildings. They were likely used to cook various types of dishes: meat, cereals and vegetables could be roasted by means of grills and wooden skewers or plates placed directly on the embers, or they could be boiled in pots. Ovens of various sizes were identified in public and private courtyards, rooms or open spaces. It is possible to distinguish dome ovens from cooking pot supports. Dome ovens are large installations (about $3 \mathrm{~m}$ in diameter and about $0.5 \mathrm{~m}$ in height) 
characterized by a brick or stone domed combustion chamber with a curved opening at the base. The fuel and the various foods (e.g. leavened bread) could be placed on the cooktop built with stones, gravel and clay. Fig. 8: Cooking pot support from Boğazköy-Hattuša (Neve 1982) Cooking pot supports (Fig.8-9) are bellshaped installations with a diameter between $0.49 \mathrm{~m}$ and $0.75 \mathrm{~m}$. and $6-10 \mathrm{~cm}$ thick clay walls. The cooktop was usually a fire-hardened clay layer placed on another one of gravel and pottery fragments. These ovens, compared to modern tandır, with which they share many characteristics, seem to have performed more functions than only baking unleavened bread. Much more likely they can be considered supports for cooking pots placed on their upper openings (Fig.8) or tools for roasting various foods by means of hooks and skewers inserted inside their body.

\section{A MULTIDISCIPLINARY APPROACH: ZOOARCHAEOLOGY AND ARCHAEOBOTANY}

Essential data for reconstructing the diet and culinary practices widespread in the Central Plateau during the Late Bronze Age come from the recent scientific studies carried out in some Hittite sites. The archaeozoological analyses on the animal bones assembly found during the excavations of the Quadratgebäude-Horizont showed that ovine and cattle ended up in kitchens only when they were already old and their meat was no longer high quality, whereas pork, although found at low frequency, was mainly a source of meat as well as wild animals (Hollestein \& Middea 2016). Similarly, the analysis of the residues and of the archaeobotanical findings conducted at Kuşaklı Šarišša, proved that also the production of two types of beer and bulgur was practiced at the time (Müller-Karpe 2017).

\section{CONCLUSIONS AND FUTURE PERSPECTIVES}

To summarize, we can draw some preliminary conclusions:

1. The analysis of the fire installations and cooking pottery show a general homogeneity of cooking modality within the Central Anatolian during the Late Bronze Age. This continuity seems to attest the existence of a Hittite culinary tradition, proven by the presence of baking plates which, after appearing concurrently the formation of the Hittite Kingdom, tended to disappear with the end of it.

2. Soups, boiled meats, stews and porridges must have probably constituted the basis of the Hittite diet. At the same time, vegetables and meats may have been roasted.

3. In addition to expanding the corpus of the Late Bronze Age, it would be interesting in the future to broaden the analysis chronologically and geographically, in order to better highlight possible differences and interferences between various groups that lived in present day Turkey.

\section{REFERENCES}

HOLLESTEIN, D. \& MIDDEA G.

2016, "The faunal remains from the Square Building Horizon in the Valley West of Sarıkale, BoğazköyHattuša, Turkey (16th/15th Century BC)", in A. Schachner and J. Seeher (eds.), Boğazköy-Hattuša: Ergebnisse der Ausgrabungen 24, Walter de Gruyter GmbH, Berlin, pp. 147-154.

MIELKE, D.-P.

2006, Die Keramik vom Westhang, Kuşaklı-Sarissa 2, Marie Leidorf GmbH, Rahden/Westphalia. MÜLLER-KARPE, A.

1988, Hethitische Töpferei der oberstadt von Hattuša. ein Beitrag zur Kenntnis spätgroßreichszeitlicher Keramik und töpferbetriebe unter Zugrundelegung der grabungsergebnisse von 1978-82 in Boğazköy, Hitzeroth, Marburg/Lahn. 2017, Sarissa. Die Wiederentdeckung einer Hethitischen Königsstadt, Philipp von Zabern, Mainz.

NEVE, P.

1982 Büyükkale. Die Bauwerke. Grabungen 1954-1966 (Boğazköy Hattuša XII), Gebr. Mann Verlag, Berlin.

ORSI, V.

2018, "Reading the Late Bronze Age ceramica evidence at Usakli Hoyuk (Central Turkey). The pottery from the Area A test sounding", Anatolica 44, Leiden, pp. 179-211. 


\section{ÖZGUÇ, T.}

1988, Inandıktepe. An important cult centerin the Old Hittite Period, Türk Tarih Kurumu Basımevi, Istanbul.

PARZINGER H., SANZ R.

1992, Die Oberstadt von Hattuša: hethitische Keramik aus dem zentralen Tempelviertel. Funde aus den Ausgrabungen 1982-1987, Boğazköy- Hattuša: Ergebnisse der Ausgrabungen XV, Gebr. Mann Verlag, Berlin.

RICE P.-M.

1987, Pottery Analysis. A Sourcebook, University of Chicago Press, Chicago/London.



Fig. 1: Hittite cooking pot from Boğazköy-Hูattuša (Parzinger \& Sanz 1992)

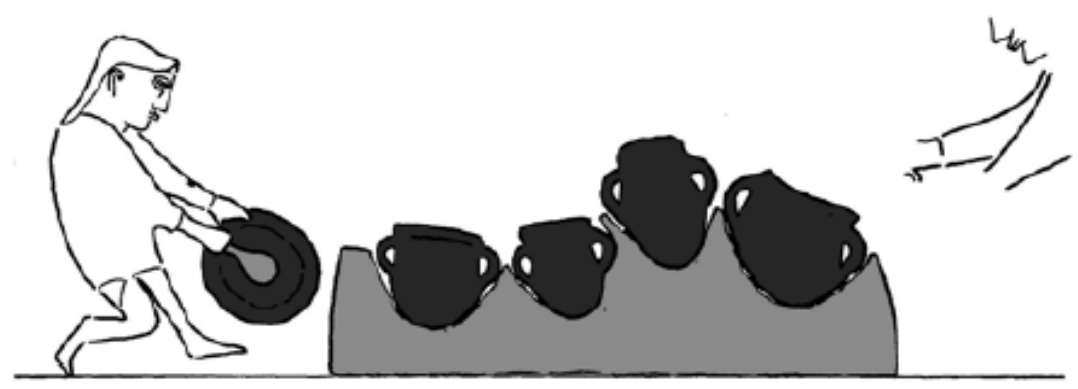

Fig. 2: Scene from Inandiktepe reliefs vase (Özgüç T. 1988) 


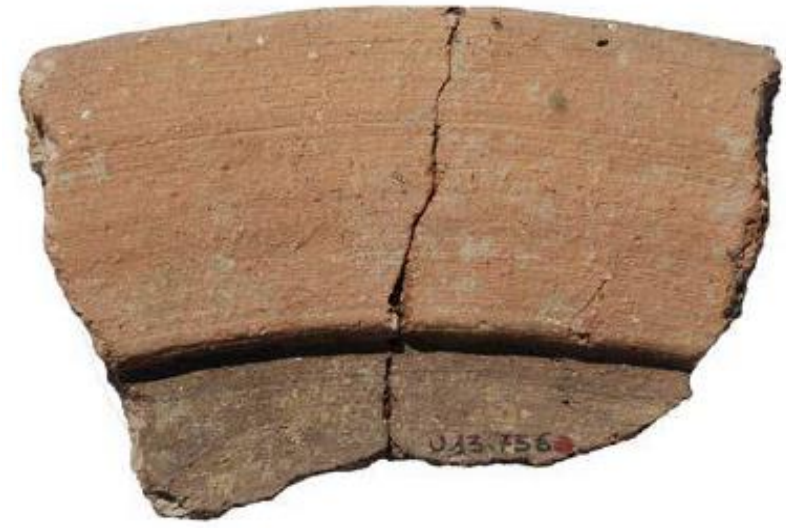

Fig. 3: Sherd of Hittite baking plate from Uşaklı Höyük (Orsi 2018)

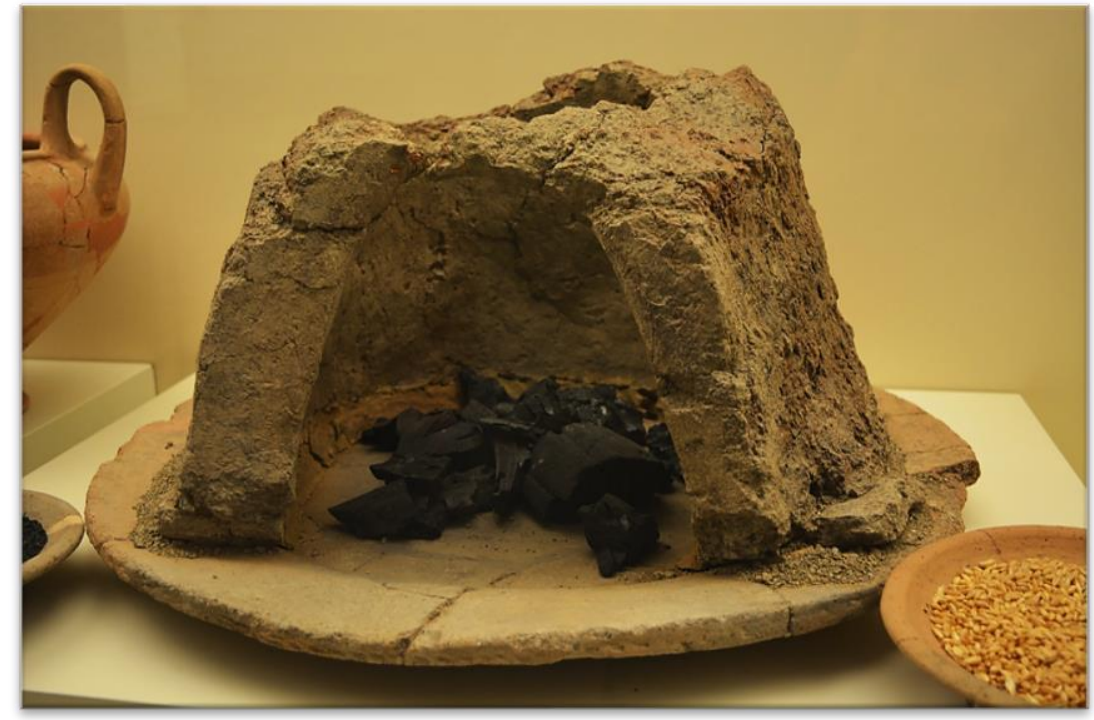

Fig. 4: Cooking pot support placed on Hittite baking plate from Büyükkaya (Bogazkale Museum)

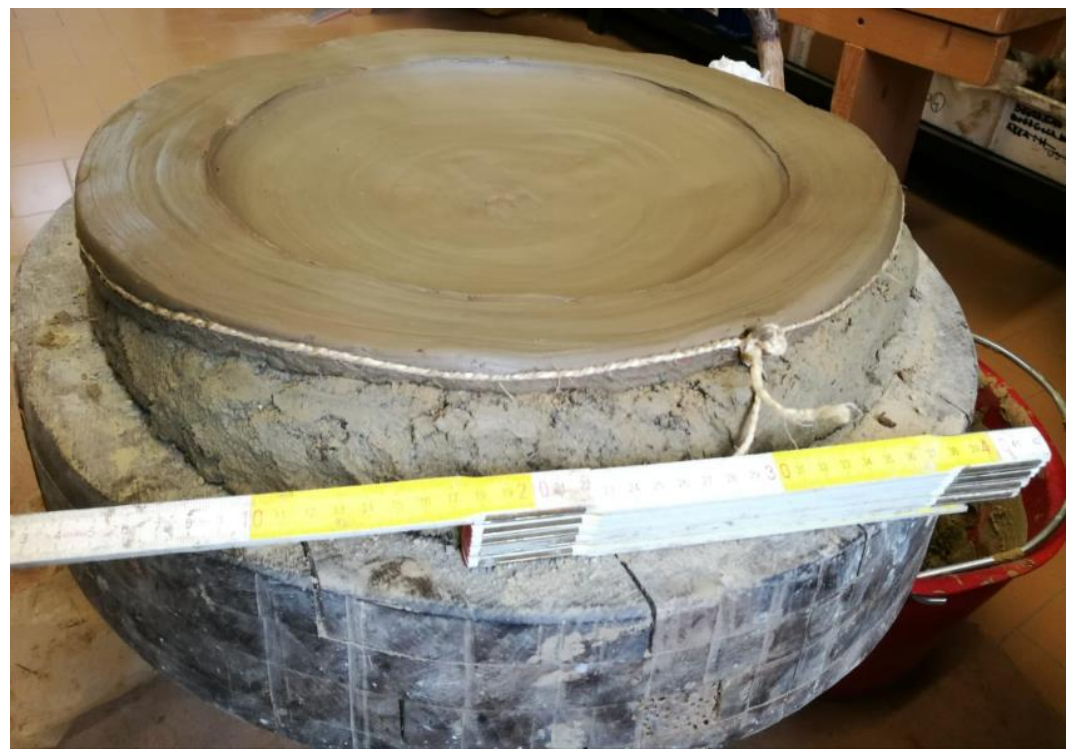

Fig. 5: Hittite backing plate reproduced in laboratory 


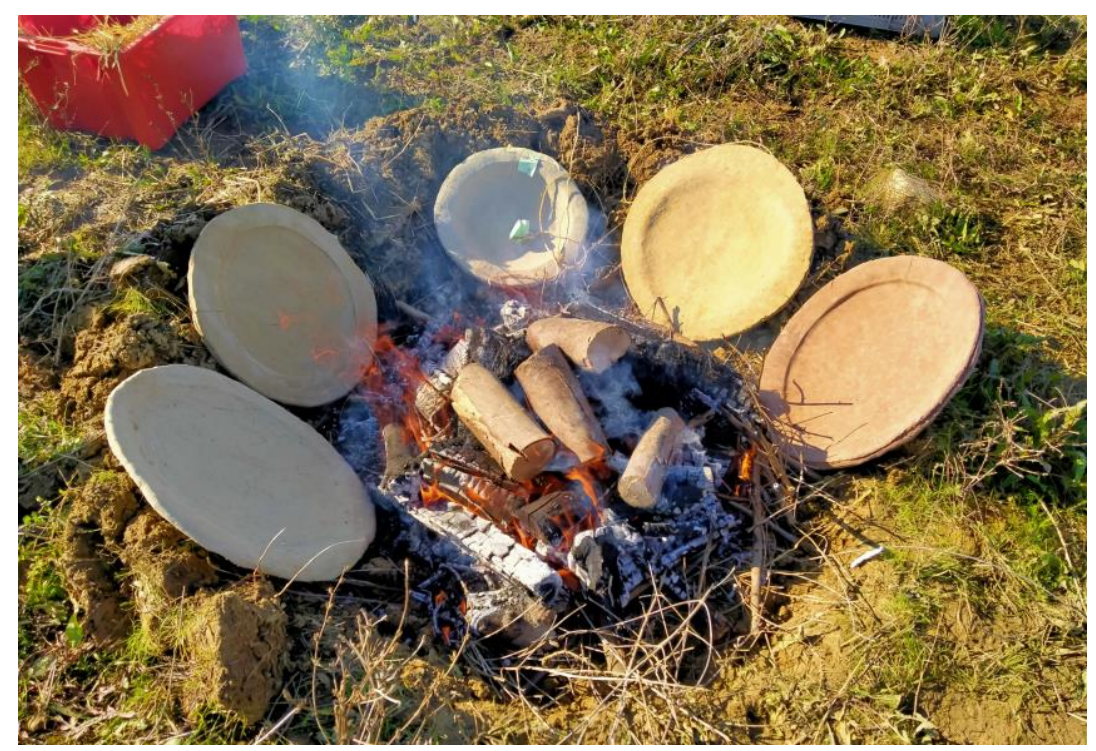

Fig. 6: Firing of Hittite baking plates produced in laboratory

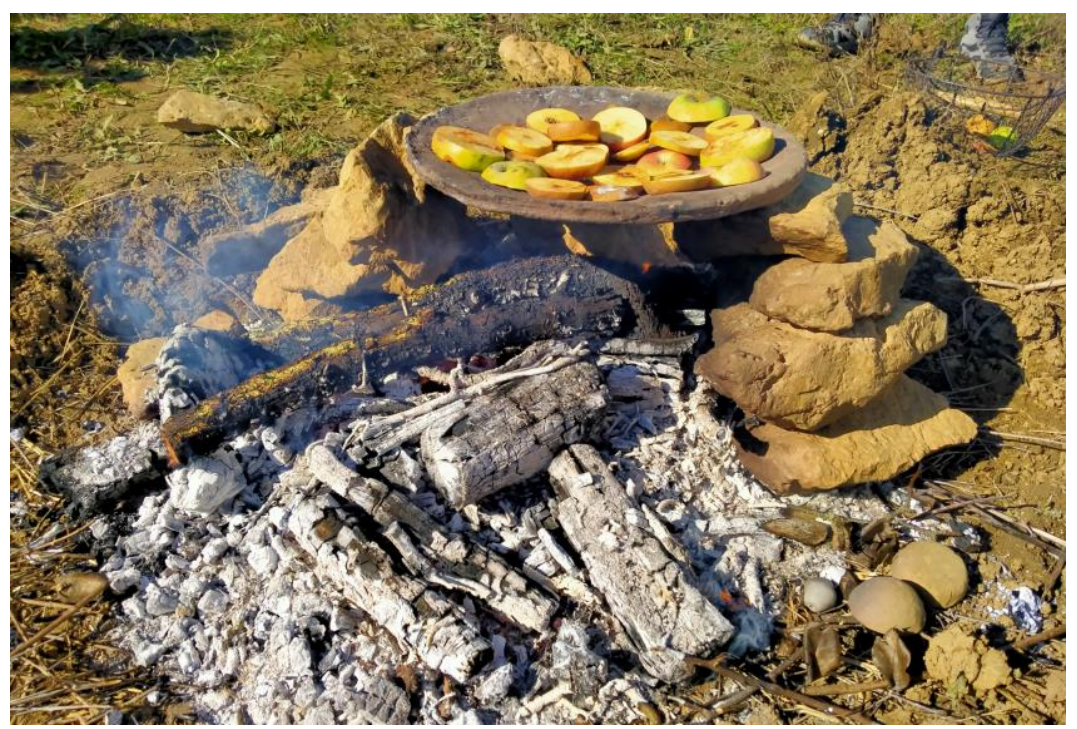

Fig. 7: Cooking apple slices by means of a laboratory Hittite backing plate

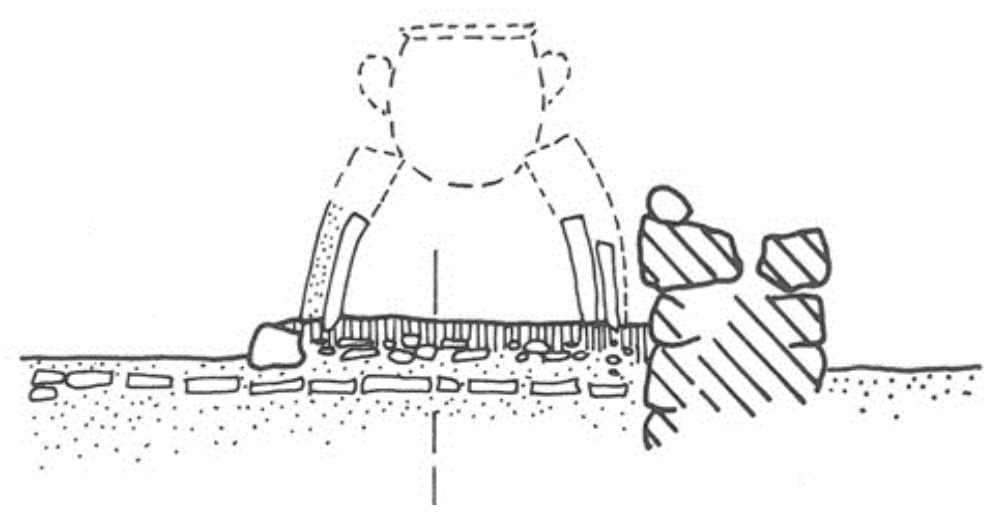

Fig. 8: Cooking pot support from Boğazköy-Hattuša (Neve 1982) 


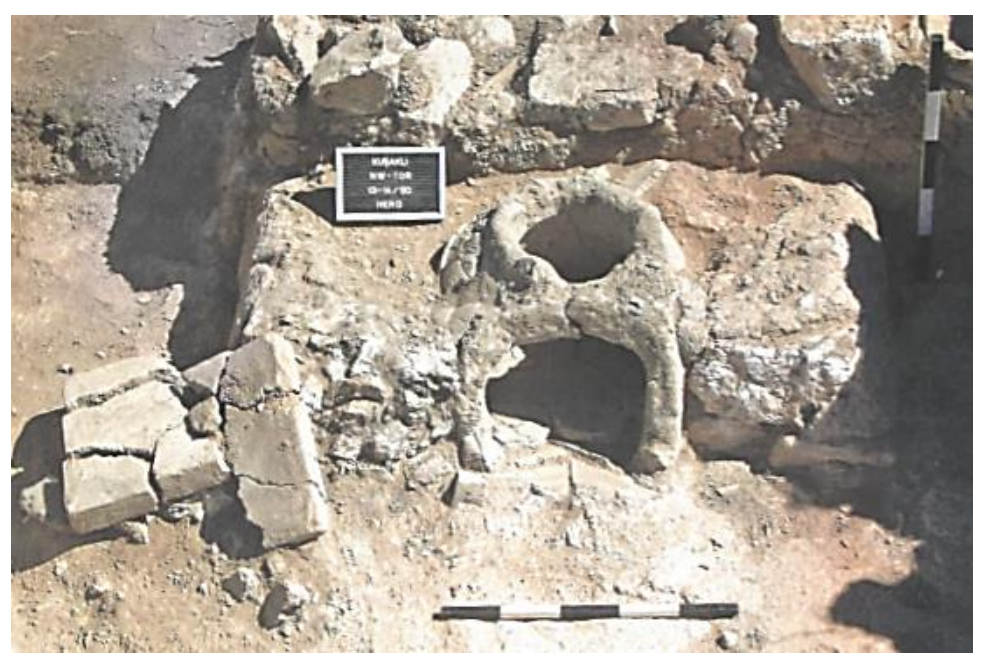

Fig. 9: Cooking pot support from Kuşaklı Šarišša (Müller-Karpe 2017) 